\title{
Vulnerability factors associated with HIV/AIDS hospitalizations: a case-control study
}

\author{
Fatores de vulnerabilidade associados às internações por HIV/aids: estudo caso controle
}

Factores de vulnerabilidad asociados a la hospitalización del VIH/SIDA: estudio de control de casos

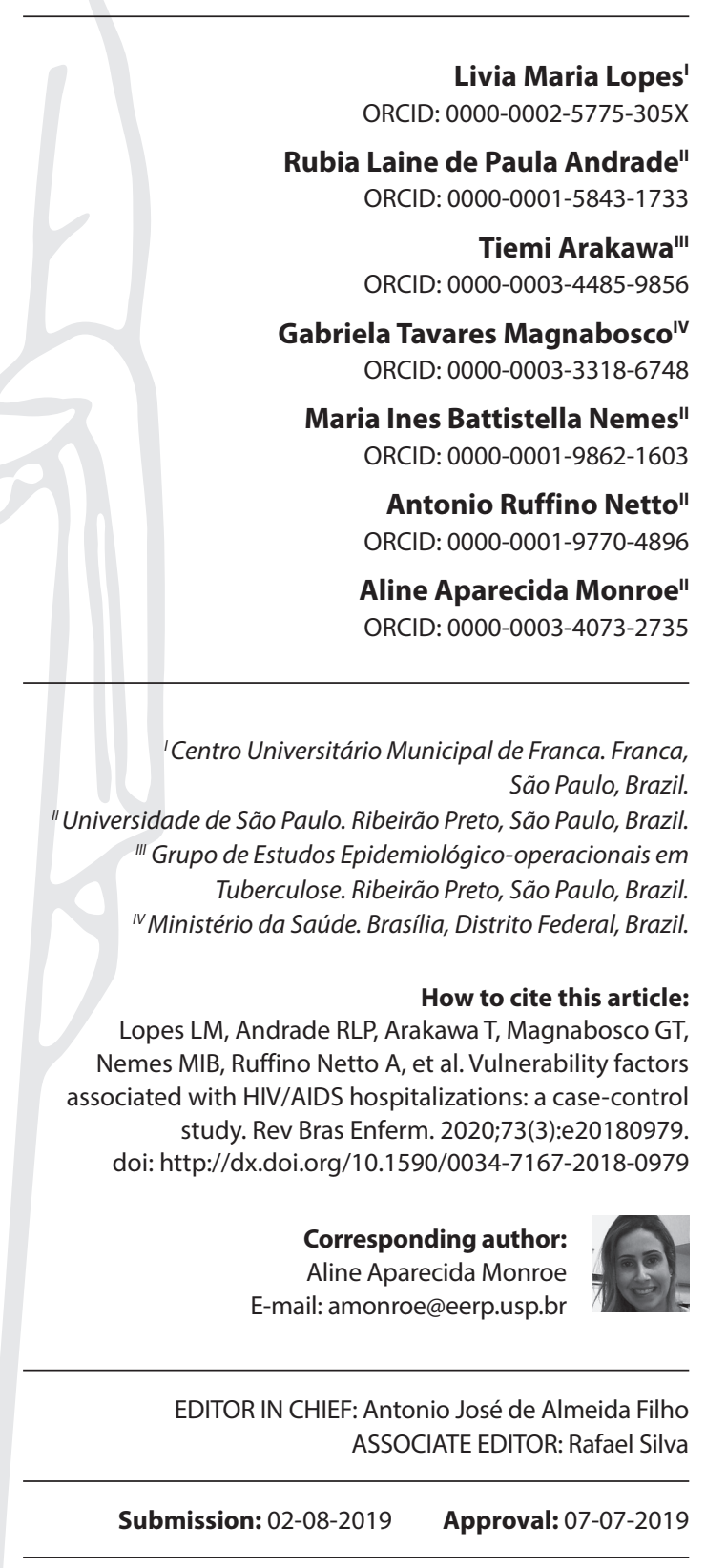

\begin{abstract}
Objectives: to identify the association between HIV/AIDS hospitalizations and factors that integrate individual, social, and programmatic vulnerabilities. Methods: a case-control study conducted in 2014 in a municipality in the state of São Paulo. "Cases" included people living with HIV (PLHIV) hospitalized and "control" those who were outpatients. Interviews were conducted using a tool with sociodemographic variables, clinical characteristics and other vulnerabilities. Data were analyzed by conditional logistic regression. Results: fifty-six cases and 112 control participated. Risk factors for HIV hospitalization were: unemployed and retired individuals; homeless people; non-antiretroviral users; individuals who did not regularly attend returns. Access to social workers was a protective factor for hospitalization. Conclusions: this research contributed to measure the social, individual and programmatic vulnerabilities that interfere with HIV worsening and, consequently, unfavorable outcome such as hospitalization.

Descriptors: Acquired Immunodeficiency Syndrome; Vulnerable Populations; Hospitalization; Delivery of Health Care; Public Health.
\end{abstract}

\section{RESUMO}

Objetivos: identificar a associação entre as internações por HIV/aids e os fatores que integram as vulnerabilidades individuais, sociais e programáticas. Métodos: estudo caso-controle realizado em 2014 em um município do estado de São Paulo. "Casos" compreenderam pessoas que viviam com HIV (PVHIV) internadas e "controles" aquelas que faziam acompanhamento ambulatorial. Foram realizadas entrevistas utilizando um instrumento com variáveis sociodemográficas, características clínicas e outras vulnerabilidades. Os dados foram analisados por meio de regressão logística condicional. Resultados: participaram 56 casos e 112 controles. Constituíram fatores de risco para internação hospitalar por HIV: indivíduos desempregados e aposentados/do lar; pessoas em situação de rua; não usuários de antirretroviral; indivíduos que não compareciam regularmente aos retornos. Acesso à assistente social constituiu-se um fator de proteção para internação. Conclusões: esta investigação contribuiu para mensurar as vulnerabilidades sociais, individuais e programáticas que interferem na agudização do HIV e, consequentemente, no desfecho desfavorável, como a internação hospitalar.

Descritores: Síndrome de Imunodeficiência Adquirida; Populações Vulneráveis; Hospitalização; Assistência à Saúde; Saúde Pública.

\section{RESUMEN}

Objetivos: identificar la asociación entre las hospitalizaciones por VIH/SIDA y los factores que integran las vulnerabilidades individuales, sociales y del programa. Métodos: estudio de casos y controles realizado en 2014 en un municipio del estado de São Paulo. Los "casos" incluyeron a personas que viven con VIH (PVVIH) hospitalizadas y "controla" a los pacientes ambulatorios. Las entrevistas se realizaron utilizando un instrumento con variables sociodemográficas, características clínicas y otras vulnerabilidades. Los datos fueron analizados por regresión logística condicional. Resultados: participaron 56 casos y 112 controles. Los factores de riesgo de hospitalización por VIH fueron: personas desempleadas y jubiladas; personas sin hogar; usuarios no antirretrovirales; individuos que no asistieron regularmente a las declaraciones. El acceso a los trabajadores sociales fue un factor protector para la hospitalización. Conclusiones: esta investigación contribuyó a medir las vulnerabilidades sociales, individuales y programáticas que interfieren con la agudización del VIH y, en consecuencia, el resultado desfavorable, como la hospitalización. Descriptores: Síndrome de Inmunodeficiencia Adquirida; Poblaciones Vulnerables; Hospitalización; Prestación de Atención de Salud; Salud Pública. 
Vulnerability factors associated with HIV/AIDS hospitalizations: a case-control study Lopes LM, Andrade RLP, Arakawa T, Magnabosco GT, Nemes MIB, Ruffino Netto A, et al.

\section{INTRODUCTION}

More than 30 years later, there have been numerous advances in health policies that involve HIV/AIDS prevention, diagnosis and treatment ${ }^{(1)}$. Nevertheless, HIV infection remains one of the world's most serious health challenges, as it has undergone an epidemiological transition from acute disease (AIDS) to a chronic condition (individuals infected with the virus). There was an impact on the need for long-term coordinated care in an essentially reactive, fragmented and episodic healthcare system ${ }^{(2)}$. Such characteristics often lead to non-retention of the individual to health services, with consequent clinical worsening and need for hospitalization ${ }^{(3)}$.

In 2012, there were 35,917 HIV/AIDS hospitalizations in Brazil, with the Southeast region accounting for $42.0 \%(15,075)$ of these cases and the state of São Paulo for $25.9 \%(9,312)^{(4)}$. It is worth noting that many of the characteristics presented about HIV/AIDS hospitalizations are addressed in the scientific literature in light of the concept of vulnerability ${ }^{(5)}$. Therefore, this study follows this line and adopts as a concept of vulnerability the set of individual elements (subjective, biological and behavioral), social (economic and social adversities) and programmatic (prevention, education, control and assistance programs, developed in all levels of health care) that make individuals and groups susceptible to health issues ${ }^{(6)}$.

In order to know the scientific literature on aspects related to HIV/ AIDS hospitalizations, a bibliographic survey was conducted in 2015. There was identification of 26 articles that, in summary, describe the complexity and challenges surrounding the HIV approach, making case management transcend biological and clinical factors, aggregating social, individual, and cultural elements. Such complexity, linked to the chronic character of the infection, is surrounded by structural weaknesses of health services. These services have fragmented care, and a biologicist and physician-centered approach that, in turn, may incur clinical complications and hospitalizations.

Given this, the present study raises the hypothesis that there are individual, social and programmatic risk factors associated with HIV hospitalizations.

\section{OBJECTIVES}

To identify the association between HIV/AIDS hospitalizations and factors that integrate individual, social, and programmatic vulnerabilities.

\section{METHODS}

\section{Ethical aspects}

In compliance with Resolution guidelines of the Brazilian National Health Board (CNS - Conselho Nacional de Saúde) 466/12, this study was approved by the Research Ethics Committee of Universidade de São Paulo's Escola de Enfermagem de Ribeirão Preto, under protocol 25096113.0.0000.5393.

\section{Design, period and place of study}

A case-control epidemiological study guided by the STROBE tool, conducted in 2014 in a municipality in the state of São
Paulo's countryside, which had an estimated population of approximately 650,000 inhabitants in 2015.

Outpatient follow-up of HIV/AIDS cases diagnosed in the city is performed by specialized teams distributed in five Specialized Care Services (SAE - Serviços de Assistência Especializada). These services have the backing of a large public hospital to assist in cases requiring hospitalization. This hospital was responsible for 540 HIV/AIDS hospitalizations in 2015 and also performed outpatient follow-up for patients that were hospitalized.

\section{Population or sample; inclusion and exclusion criteria}

Individuals with HIV/AIDS hospitalized in 2014 and registered in the hospital's Hospitalization System (SIH - Sistema de Internação Hospitalar) were defined as "cases". Individuals with ICD related to HIV/AIDS were included: B20.0 to B24; Z20; Z20.6; Z21; R75. Individuals living with HIV/AIDS (PLHIV/AIDS) in outpatient followup in the five municipality SAE, with no hospitalization history in the last 12 months, were defined as "control". The following inclusion criteria were considered: aged 18 years and over, and resident in the municipality of study; and as exclusion: subjects unable to answer the questionnaire. Two control individuals (112) were selected for each case (56), which were matched according to the area of residence of the case and the area covered by the follow-up SAE.

\section{Study protocol}

For the study, data were collected from primary and secondary sources. Primary sources consisted of PLHIV/AIDS; Secondary sources were: Hospital Information System accessed at the study hospital; Hospital and SAE Clinical Records; and Electronic Records of the municipal public health network.

The data collection tool was developed based on the Ministry of Health Recommendations for antiretroviral therapy (ART) in HIV-infected adults ${ }^{(7)}$; in the outpatient follow-up protocol of the patient with HIV/AIDS of the Minas Gerais State Hospital Foundation (Fundação Hospitalar do Estado de Minas Gerais) ${ }^{(8)}$; in the rapid assessment methodology of the organizational characteristics and performance of SUS (Sistema Único de Saúde - Brazilian Unified Health System) care services ${ }^{(9)}$; and the constituent elements of Health Care Networks ${ }^{(2)}$. The tool was subjected to content and semantic analysis by subject matter experts. Variables corresponding to individual/social (sociodemographic, behavioral and clinical) and programmatic (case follow-up) vulnerabilities were selected for this study.

In order to ensure comparability of the collected data, the same tool was used to interview cases and control, as well as a single interviewer for both. Importantly, the sensitivity and specificity of the interviews were not tested.

\section{Analysis of results, and statistics}

In the data analysis, descriptive techniques and Chi-Square analysis were used, which allowed the identification of the independent variables that were submitted to conditional 
Vulnerability factors associated with HIV/AIDS hospitalizations: a case-control study

logistic regression analysis. For this analysis, the dependent variable was HIV hospitalization presence (yes or no).

To perform the logistic regression analysis, all variables were entered together in the model, except those obtained by secondary sources, since their quality was questioned throughout the analyzes. After insertion of all variables in the model, those with the highest $\mathrm{p}$ value were removed individually, one by one and a new adjustment was made with the remaining variables.

From the chosen model, adjusted and unadjusted odds ratios (OR) were established along with the respective Confidence Intervals. The significance level adopted in all analyzes was $5 \%$ (alpha = 0.05). The Epicalc library from program $R$ version 3.0.1 was used.

\section{RESULTS}

Regarding the demographic profile of the PLHIV/AIDS interviewed, the individuals were mostly male $(49.4 \%)$, aged 40 to 60 years $(54.8 \%)$, nonwhite $(56.6 \%)$ and with presence of any religious belief (71.4\%). Regarding social variables, most individuals (73.2\%) did not consume alcohol. A significant statistical association was identified between HIV/AIDS hospitalization and the variables education, occupation, drug use, prison history and performance of benefits in exchange for sex. Among the clinical variables, almost half of the individuals had another chronic condition and $86.3 \%$ accepted their diagnosis of HIV. Other variables such as regular use of ART, difficulty taking ART, and treatment withdrawal were also statistically significant associated with HIV/AIDS hospitalization (Table 1).

As for programmatic vulnerabilities, "satisfaction with care", "lack of scheduled return appointments", "appointment with infectious physician", "appointment with nursing staff" and
Table 1 - Frequency distribution of sociodemographic and behavioral characteristics (individual/social vulnerabilities) of people living with HIV/AIDS in Ribeirão Preto, São Paulo, Brzazil, 2014

\begin{tabular}{|c|c|c|c|c|c|c|c|c|c|}
\hline \multicolumn{3}{|c|}{ Individual/social vulnerabilities } & \multicolumn{2}{|c|}{$\begin{array}{l}\text { Hospitalized } \\
\quad(\mathrm{N}=56)\end{array}$} & \multicolumn{2}{|c|}{$\begin{array}{l}\text { Not hospitalized } \\
\quad(\mathrm{N}=112)\end{array}$} & \multicolumn{2}{|c|}{$\begin{array}{c}\text { Total } \\
(n=168)\end{array}$} & \multirow{3}{*}{$\begin{array}{c}\boldsymbol{p}^{\mathrm{a}} \\
0.662\end{array}$} \\
\hline \multirow[t]{2}{*}{ Sex } & \multirow{2}{*}{\multicolumn{2}{|c|}{$\begin{array}{l}\text { Male } \\
\text { Female }\end{array}$}} & 29 & 51.8 & 54 & 48.2 & 83 & 49.4 & \\
\hline & & & 27 & 48.2 & 58 & 51.8 & 85 & 50.6 & \\
\hline \multirow[t]{3}{*}{ Age group } & \multirow{2}{*}{\multicolumn{2}{|c|}{$\begin{array}{l}18-39 \text { years } \\
40-60 \text { vears }\end{array}$}} & 21 & 37.5 & 28 & 25.0 & 49 & 29.1 & \multirow{3}{*}{0.175} \\
\hline & \multirow{2}{*}{\multicolumn{2}{|c|}{$>60$ years }} & 32 & 57.1 & 60 & 53.6 & 92 & 54.8 & \\
\hline & & & 3 & 5.4 & 24 & 21.4 & 27 & 16.1 & \\
\hline \multirow[t]{2}{*}{ Color/Race } & \multirow{2}{*}{\multicolumn{2}{|c|}{$\begin{array}{l}\text { White } \\
\text { Non-white }\end{array}$}} & 22 & 39.3 & 51 & 45.5 & 73 & 43.4 & \multirow{2}{*}{0.441} \\
\hline & & & 34 & 60.7 & 61 & 54.5 & 95 & 56.6 & \\
\hline \multirow[t]{3}{*}{ Schooling } & \multirow{2}{*}{\multicolumn{2}{|c|}{$\begin{array}{l}\text { No SCH or incomplete HE } \\
\text { Complete ES }\end{array}$}} & 32 & 57.1 & 47 & 41.9 & 79 & 47.1 & \multirow{3}{*}{0.044} \\
\hline & & & 11 & 19.7 & 17 & 15.2 & 28 & 16.6 & \\
\hline & \multicolumn{2}{|c|}{ Complete HS/complete HE } & 13 & 23.2 & 48 & 42.9 & 61 & 36.3 & \\
\hline \multirow[t]{3}{*}{ Occupation } & \multirow{3}{*}{\multicolumn{2}{|c|}{$\begin{array}{l}\text { Employed/Self-Employed } \\
\text { Unemployed } \\
\text { Others (retired/homemaker) }\end{array}$}} & 17 & 30.4 & 61 & 54.5 & 78 & 46.5 & \multirow{3}{*}{0.002} \\
\hline & & & 26 & 46.4 & 24 & 21.4 & 50 & 29.7 & \\
\hline & & & 13 & 23.2 & 27 & 24.1 & 40 & 23.8 & \\
\hline \multirow{2}{*}{\multicolumn{2}{|c|}{ Religion }} & Yes & 40 & 71.4 & 94 & 83.9 & 134 & 79.7 & \multirow{2}{*}{0.573} \\
\hline & & No & 16 & 28.6 & 18 & 16.1 & 34 & 20.3 & \\
\hline \multirow{2}{*}{\multicolumn{2}{|c|}{ Homeless }} & Yes & 15 & 26.8 & 1 & 0.9 & 16 & 9.5 & \multirow{2}{*}{0.000} \\
\hline & & No & 41 & 73.2 & 111 & 99.1 & 152 & 90.5 & \\
\hline \multirow{2}{*}{\multicolumn{2}{|c|}{ HIV/AIDS diagnosis acceptance }} & Yes & 46 & 82.1 & 99 & 88.4 & 145 & 86.3 & 0.266 \\
\hline & & No & 10 & 17.9 & 13 & 11.6 & 23 & 13.7 & 0.200 \\
\hline Alcoholic bev & ge & Yes & 20 & 35.7 & 25 & 22.3 & 45 & 26.8 & 0,064 \\
\hline consumption & & No & 36 & 64.3 & 87 & 77.7 & 123 & 73.2 & 0.004 \\
\hline Drug use & & Yes & 13 & 23.2 & 10 & 8.9 & 23 & 13.7 & 0011 \\
\hline & & No & 43 & 76.8 & 102 & 91.1 & 145 & 86.3 & 0.011 \\
\hline Prison history & & Yes & 17 & 30.3 & 9 & 8.1 & 26 & 15.5 & 000 \\
\hline & & No & 39 & 69.7 & 103 & 91.9 & 142 & 84.5 & 0.000 \\
\hline Benefits in ex & hange for sex & Yes & 10 & 17.8 & 7 & 6.2 & 17 & 10.1 & \\
\hline & & No & 46 & 82.2 & 105 & 93.8 & 151 & 89.9 & 0.018 \\
\hline Chronic cono & ion presence & Yes & 29 & 51.8 & 53 & 47.3 & 82 & 48.8 & 0,585 \\
\hline & & No & 27 & 48.2 & 59 & 52.7 & 86 & 51.2 & 0.585 \\
\hline Regular ART & & Yes & 22 & 39.3 & 94 & 83.9 & 116 & 69.1 & 0.000 \\
\hline & & No & 34 & 60.7 & 18 & 16.1 & 52 & 30.9 & 0.000 \\
\hline Difficulty to $t$ & ke ART & Yes & 33 & 58.9 & 19 & 16.9 & 52 & 30.9 & 0.000 \\
\hline & & No & 23 & 41.1 & 93 & 83.1 & 116 & 69.1 & 0.000 \\
\hline ART withdrav & & Yes & 34 & 60.7 & 20 & 17.8 & 54 & 32.8 & 0.000 \\
\hline & & No & 22 & 39.3 & 92 & 82.2 & 114 & 67.8 & \\
\hline
\end{tabular}

Note: SCH - schooling; ES - elementary school; HS - high school; HE - higher education; ART - antiretroviral therapy aChi-square test $(p<0.05)$.

"care with social worker" presented statistical significance for the Chi-square test (Table 2).

The best model of logistic regression analysis consisted of seven variables. It was found that the unemployed had 3.63 and the retired/homemaker 7.14 times more likely to intern than employed or self-employed. Homeless people were 10.18 times more likely to be interned than those in the opposite situation. Non-ART users were 9.68 more likely than users. Those who were unsatisfactorily attending return visits were 7.62 times more likely to be hospitalized than those who were absent; undergoing care with a social worker was a protective factor for HIV hospitalization (Table 3 ). 
Table 2 - Frequency distribution of health care aspects of people living with HIV/AIDS in Ribeirão Preto, São Paulo, Brazil, 2014

\begin{tabular}{|c|c|c|c|c|c|c|c|c|}
\hline \multirow[t]{2}{*}{ Programmatic vulnerability } & & \multicolumn{2}{|c|}{$\begin{array}{l}\text { Hospitalized } \\
\quad(\mathrm{N}=56)\end{array}$} & \multicolumn{2}{|c|}{$\begin{array}{l}\text { Not hospitalized } \\
\quad(\mathrm{N}=112)\end{array}$} & \multicolumn{2}{|c|}{$\begin{array}{c}\text { Total } \\
(n=168)\end{array}$} & \multirow[t]{2}{*}{$p^{*}$} \\
\hline & & $\mathbf{n}$ & $\%$ & $\mathbf{n}$ & $\%$ & $\mathbf{n}$ & $\%$ & \\
\hline Satisfaction with outpatient care & $\begin{array}{l}\text { Satisfactory } \\
\text { Unsatisfactory }\end{array}$ & $\begin{array}{c}47 \\
9\end{array}$ & $\begin{array}{l}83.9 \\
16.1\end{array}$ & $\begin{array}{l}107 \\
5\end{array}$ & $\begin{array}{c}95.5 \\
4.5\end{array}$ & $\begin{array}{c}154 \\
14\end{array}$ & $\begin{array}{l}91.6 \\
8.4\end{array}$ & 0.010 \\
\hline Difficulties in receiving care & $\begin{array}{l}\text { Satisfactory } \\
\text { Unsatisfactory }\end{array}$ & $\begin{array}{c}52 \\
4\end{array}$ & $\begin{array}{l}92.8 \\
7.1\end{array}$ & $\begin{array}{c}109 \\
3\end{array}$ & $\begin{array}{l}97.3 \\
2.7\end{array}$ & $\begin{array}{c}161 \\
7\end{array}$ & $\begin{array}{c}95.8 \\
4.2\end{array}$ & 0.172 \\
\hline Return appointment attendance & $\begin{array}{l}\text { Satisfactory } \\
\text { Unsatisfactory }\end{array}$ & $\begin{array}{l}24 \\
32\end{array}$ & $\begin{array}{l}42.8 \\
57.2\end{array}$ & $\begin{array}{l}95 \\
17\end{array}$ & $\begin{array}{l}84.8 \\
15.2\end{array}$ & $\begin{array}{c}119 \\
49\end{array}$ & $\begin{array}{l}70.8 \\
29.2\end{array}$ & 0.000 \\
\hline Appointment with infectious physician & $\begin{array}{l}\text { Satisfactory } \\
\text { Unsatisfactory }\end{array}$ & $\begin{array}{c}51 \\
5\end{array}$ & $\begin{array}{c}91.1 \\
8.9\end{array}$ & $\begin{array}{c}112 \\
0\end{array}$ & $\begin{array}{c}100.0 \\
0.0\end{array}$ & $\begin{array}{c}163 \\
5\end{array}$ & $\begin{array}{c}97.1 \\
2.9\end{array}$ & 0.001 \\
\hline Appointment with nursing staff & $\begin{array}{l}\text { Satisfactory } \\
\text { Unsatisfactory }\end{array}$ & $\begin{array}{c}51 \\
5\end{array}$ & $\begin{array}{l}91.1 \\
8.9\end{array}$ & $\begin{array}{c}111 \\
1\end{array}$ & $\begin{array}{c}99.1 \\
0.9\end{array}$ & $\begin{array}{c}162 \\
6\end{array}$ & $\begin{array}{c}96.4 \\
3.6\end{array}$ & 0.008 \\
\hline Social worker support & $\begin{array}{l}\text { Yes } \\
\text { No }\end{array}$ & $\begin{array}{l}15 \\
41\end{array}$ & $\begin{array}{l}26.8 \\
73.2\end{array}$ & $\begin{array}{l}62 \\
50\end{array}$ & $\begin{array}{l}55.4 \\
44.6\end{array}$ & $\begin{array}{l}77 \\
91\end{array}$ & $\begin{array}{l}45.8 \\
54.1\end{array}$ & 0.000 \\
\hline Appointment with psychologist & $\begin{array}{l}\text { Satisfactory } \\
\text { Unsatisfactory }\end{array}$ & $\begin{array}{c}5 \\
51\end{array}$ & $\begin{array}{c}8.9 \\
91.1\end{array}$ & $\begin{array}{l}13 \\
99\end{array}$ & $\begin{array}{l}11.6 \\
88.4\end{array}$ & $\begin{array}{c}18 \\
150\end{array}$ & $\begin{array}{l}10.7 \\
89.3\end{array}$ & 0.596 \\
\hline Appointment with nutritionist & $\begin{array}{l}\text { Yes } \\
\text { No }\end{array}$ & $\begin{array}{c}6 \\
50\end{array}$ & $\begin{array}{l}10.7 \\
89.3\end{array}$ & $\begin{array}{c}12 \\
100\end{array}$ & $\begin{array}{l}10.7 \\
89.3\end{array}$ & $\begin{array}{c}18 \\
150\end{array}$ & $\begin{array}{l}10.7 \\
89.3\end{array}$ & --- \\
\hline Antiretroviral therapy side effect & $\begin{array}{l}\text { Satisfactory } \\
\text { Unsatisfactory }\end{array}$ & $\begin{array}{c}8 \\
48\end{array}$ & $\begin{array}{l}14.3 \\
85.7\end{array}$ & $\begin{array}{l}14 \\
98\end{array}$ & $\begin{array}{l}12.5 \\
87.5\end{array}$ & $\begin{array}{c}22 \\
146\end{array}$ & $\begin{array}{l}13.1 \\
86.9\end{array}$ & 0.746 \\
\hline Other health services use & $\begin{array}{l}\text { Yes } \\
\text { No }\end{array}$ & $\begin{array}{l}49 \\
7\end{array}$ & $\begin{array}{l}87.5 \\
12.5\end{array}$ & $\begin{array}{l}88 \\
24\end{array}$ & $\begin{array}{l}78.6 \\
21.4\end{array}$ & $\begin{array}{l}137 \\
31\end{array}$ & $\begin{array}{l}81.5 \\
18.5\end{array}$ & 0.159 \\
\hline Emergency Care Units use & $\begin{array}{l}\text { Yes } \\
\text { No }\end{array}$ & $\begin{array}{c}47 \\
9\end{array}$ & $\begin{array}{l}83.9 \\
16.1\end{array}$ & $\begin{array}{l}83 \\
29\end{array}$ & $\begin{array}{l}74.1 \\
25.9\end{array}$ & $\begin{array}{c}130 \\
38\end{array}$ & $\begin{array}{l}77.4 \\
22.6\end{array}$ & 0.151 \\
\hline Basic Health Units use & $\begin{array}{l}\text { Yes } \\
\text { No }\end{array}$ & $\begin{array}{l}18 \\
38\end{array}$ & $\begin{array}{l}32.1 \\
67.9\end{array}$ & $\begin{array}{l}38 \\
74\end{array}$ & $\begin{array}{l}33.9 \\
66.1\end{array}$ & $\begin{array}{c}56 \\
112\end{array}$ & $\begin{array}{l}33.3 \\
66.6\end{array}$ & 0.817 \\
\hline Health insurance use & $\begin{array}{l}\text { Yes } \\
\text { No }\end{array}$ & $\begin{array}{c}5 \\
51\end{array}$ & $\begin{array}{c}9.9 \\
91.1\end{array}$ & $\begin{array}{l}18 \\
94\end{array}$ & $\begin{array}{l}16.1 \\
83.9\end{array}$ & $\begin{array}{c}23 \\
145\end{array}$ & $\begin{array}{l}13.7 \\
86.3\end{array}$ & 0.204 \\
\hline Medical appointment payment & $\begin{array}{l}\text { Yes } \\
\text { No }\end{array}$ & $\begin{array}{l}10 \\
46\end{array}$ & $\begin{array}{l}17.8 \\
82.2\end{array}$ & $\begin{array}{c}12 \\
100\end{array}$ & $\begin{array}{l}10.7 \\
89.3\end{array}$ & $\begin{array}{c}22 \\
146\end{array}$ & $\begin{array}{l}13.1 \\
86.9\end{array}$ & 0.195 \\
\hline Question about living conditions & $\begin{array}{l}\text { Yes } \\
\text { No }\end{array}$ & $\begin{array}{l}26 \\
30\end{array}$ & $\begin{array}{l}46.4 \\
53.6\end{array}$ & $\begin{array}{l}63 \\
49\end{array}$ & $\begin{array}{l}56.3 \\
43.7\end{array}$ & $\begin{array}{l}89 \\
79\end{array}$ & $\begin{array}{l}53.0 \\
47.0\end{array}$ & 0.742 \\
\hline Question complications & $\begin{array}{l}\text { Yes } \\
\text { No }\end{array}$ & $\begin{array}{c}48 \\
8\end{array}$ & $\begin{array}{l}85.7 \\
14.3\end{array}$ & $\begin{array}{c}102 \\
10\end{array}$ & $\begin{array}{c}91.1 \\
8.9\end{array}$ & $\begin{array}{c}150 \\
18\end{array}$ & $\begin{array}{l}89.3 \\
10.7\end{array}$ & 0.289 \\
\hline Emergency health services use & $\begin{array}{l}\text { Yes } \\
\text { No }\end{array}$ & $\begin{array}{c}50 \\
6\end{array}$ & $\begin{array}{l}89.2 \\
10.7\end{array}$ & $\begin{array}{c}109 \\
3\end{array}$ & $\begin{array}{c}97.32 \\
2.68\end{array}$ & $\begin{array}{c}159 \\
9\end{array}$ & $\begin{array}{l}94.6 \\
5.36\end{array}$ & 0.113 \\
\hline
\end{tabular}

Table 3 - Risk factors analysis of people living with HIV/AIDS in Ribeirão Preto, São Paulo, Brazil, 2014

\begin{tabular}{|c|c|c|c|c|c|c|}
\hline Risk factors & & OR & $95 \% \mathrm{Cl}$ & Adj. OR & $95 \% \mathrm{Cl}$ & $p$ value \\
\hline Occupation & $\begin{array}{l}\text { Employee/Self-Employed } \\
\text { Unemployed } \\
\text { Retired/Homemaker }\end{array}$ & $\begin{array}{c}1 \\
3.93 \\
1.76\end{array}$ & $\begin{array}{l}{[1.75-8.83]} \\
{[0.70-4.46]}\end{array}$ & $\begin{array}{c}1 \\
3.63 \\
7.14\end{array}$ & $\begin{array}{l}{[1.06-12.51]} \\
{[1.38-36.94]}\end{array}$ & $0.017^{a}$ \\
\hline Homeless & $\begin{array}{l}\text { Yes } \\
\text { No }\end{array}$ & $\begin{array}{c}30.0 \\
1\end{array}$ & [3.96-227.11] & $\begin{array}{c}10.18 \\
1\end{array}$ & {$[1.06-97.80]$} & $0.016^{\mathrm{a}}$ \\
\hline Drug use & $\begin{array}{l}\text { Yes } \\
\text { No }\end{array}$ & $\begin{array}{c}3.46 \\
1\end{array}$ & [1.29-9.31] & $\begin{array}{c}0.18 \\
1\end{array}$ & {$[0.02-1.85]$} & 0.127 \\
\hline Benefits in exchange for sex & $\begin{array}{l}\text { Yes } \\
\text { No }\end{array}$ & $\begin{array}{c}6.90 \\
1\end{array}$ & {$[1.45-32.78]$} & 1.13 & {$[0.06-21.23]$} & 0.935 \\
\hline Regular ART & $\begin{array}{l}\text { Yes } \\
\text { No }\end{array}$ & $\begin{array}{c}1 \\
6.75\end{array}$ & [3.09-14.76] & $\begin{array}{c}1 \\
9.68\end{array}$ & {$[2.38-39.40]$} & $0.001^{a}$ \\
\hline Return appointments attendance & $\begin{array}{l}\text { Satisfactory } \\
\text { Unsatisfactory }\end{array}$ & $\begin{array}{c}1 \\
7.25\end{array}$ & [3.16-16.65] & $\begin{array}{c}1 \\
7.62\end{array}$ & {$[1.85-31.50]$} & $0.002^{a}$ \\
\hline Social worker & $\begin{array}{l}\text { Yes } \\
\text { No }\end{array}$ & $\begin{array}{c}1 \\
0.27\end{array}$ & {$[0.13-0.59]$} & $\begin{array}{c}1 \\
0.25\end{array}$ & {$[0.07-0.88]$} & $0.020^{\mathrm{a}}$ \\
\hline
\end{tabular}

Caption: ART - antiretroviral therapy; ${ }^{a}$ Presents statistical significance.

\section{DISCUSSION}

The findings of the study allow reflections on the complexity that permeates PLHIV/AIDS diagnosis and clinical followup in interface with individual and social issues. Among the sociodemographic characteristics, lack of occupation was a risk factor for HIV hospitalization. Being employed or acting as a self-employed person is a protective element against non-hospitalization. Added to this, there is the idea that an income source presence is crucial for maintaining the quality and standard of living ${ }^{(10)}$ in a context of political instability and economic polarization.

Another variable that presented as a significant risk factor for HIV hospitalization was related to people who were homeless. This population is considered as a multifaceted and multidimensional phenomenon, but with some common characteristics, such as precariousness in the socio-family and work dimensions, as well as feelings such as isolation, loneliness, and non-belonging ${ }^{(11)}$.

The decision to remain homeless is often influenced by structural and biographical elements. Thus, understanding and even facing this reality implies the recognition of the living conditions of these subjects and the availability of social services in each city ${ }^{(12)}$.

Considering this requirement, it is important to highlight that the studied municipality has teams to approach the homeless population in specific services such as the Screening and Referral Center for Immigrant/Itinerant and Homeless (Central de Triagem e Encaminhamento ao Imigrante/ltinerante e Morador de Rua), and the Specialized Reference Center for Care for the Homeless (Centro de Referência Especializado para Atendimento à 
População em Situação de Rua). Such services provide assistance to people in situations of vulnerability or social exclusion. They provide temporary reception, opportunities to strengthen the family, personal and social bond, in order to promote their inclusion, autonomy and independence of subjects, through participation in socio-educational activities and operational workshops ${ }^{(13)}$.

Additionally, the municipality has health care organized in Health Districts, and the STD/AIDS, Viral Hepatitis and Tuberculosis Program has, in some SAE, care with professional social worker and outreach street office. Its main focus is crack users and pregnant women with street syphilis. Given the complexity of care provided to this population, in addition to the availability and provision of health actions and services, it is necessary to commit teams to promote quality work. Thus, there would be a guarantee of intersectoriality and integration between the various social and health care services belonging to the healthcare network $^{(14)}$. It is intended to reduce the existing vulnerabilities in this setting of poverty and social exclusion. Thus, such efforts require a political context aligned with proposals for identifying vulnerable groups and focusing on actions and services, rescuing and valuing proposals for social inclusion and development.

Other characteristics such as drug use, non-use of antiretrovirals (ARVs) regularly were also risk factors for HIV/AIDS hospitalization, corroborating another study about vulnerabilities that directly reflect the health condition of PLHIV/AIDS ${ }^{(15)}$. Regarding drug use and sex in exchange for benefits, it must be considered that other social aspects may have overlapped with these variables as determinants of hospitalizations.

Regarding ARV use, according to the Ministry of Health, it is necessary to ensure at least $80 \%$ of the prescribed doses to obtain a satisfactory therapeutic response. Thus, poor adherence is identified as one of the main causes of therapeutic failure and, consequently, disease worsening ${ }^{(7)}$.

Brazil is among the countries that adopted in 2014 the target 90/90/90 recommended by the United Nations Joint Program on HIV/AIDS (UNAIDS) and the World Health Organization, which has, by $2020,90 \%$ of people diagnosed with HIV. Of this group, 90\% undergo ARV treatment; and among these, 90\% with undetectable viral load, which indicates the success of the therapeutic method applied ${ }^{(16)}$. In view of this, adherence to ART has been a widely discussed issue in the field of HIV/ AIDS care ${ }^{(7,17)}$. In addition to the continuity and follow-up of appropriate treatment, it is a challenge for Brazil to reach the global goal set by the Ministry of Health ${ }^{(18)}$. From this perspective, it is commonly agreed that drug regime abandonment is one of the major obstacles to health teams in following up on PLHIV/AIDS ${ }^{(19)}$. This challenge can be overcome by ensuring adherence to ART in a context immersed by vulnerabilities of different natures and dimensions, such as individual, social and program vulnerabilities ${ }^{(7,18,20)}$. This largely depends on the information provided by the health team. Thus, the preparation of professionals and ability to articulate with other services and sectors can maximize adherence to treatment.

Thus, to confront HIV/AIDS, more comprehensive, robust and capable of articulating public actors and sectors of society is needed. Thus, the monitoring of PLHIV/AIDS will be continuous and there will be the establishment of bond with these citizens, as well as a care plan with emphasis for the integration of the multidisciplinary team. There will also be monitoring of ARV withdrawal at the pharmacy and CD4 + T cell count and viral load ${ }^{(21)}$.

Furthermore, it was identified between the programmatic vulnerabilities that missing return visits and non-access to social workers were important risk factors for HIV/AIDS hospitalization. This, once again, shows that in care, it is necessary to focus on social and individual issues, in addition to establishing integrated and continuous care ${ }^{(22)}$, within and between health services of the care network.

Care with the social worker was considered a protective factor against HIV non-hospitalization in the entire population. This professional has skills and abilities, with potential for the necessary confrontations in order to recognize and reduce the social vulnerabilities present in the context of PLHIV/AIDS. Moreover, he has the task of speeding up the insertion and integration into the world of work; facilitate access to public transport; predict and promote processes that expedite actions for financial aid; reconcile and integrate SAE activities with other services, NGOs and self-help houses ${ }^{(23)}$.

Social work is understood as a set of actions aimed at the impoverished segments of the population. As with health, the Federal Constitution of 1988 represents a fundamental milestone, as it recognizes social assistance as a public social protection policy, which operates through a single federative system, the Brazilian Unified Social Assistance System (Sistema Único de Assistência Social). In this sense, the social policy linked to health and social security policies make up the Brazilian social security system, making possible the social protection, which is the set of social security that a society, in solidarity, guarantees its citizens ${ }^{(24)}$.

In HIV prevention and management policies, there have been many advances in the biomedical field. However, it is important to highlight the difficulties of implementing successful actions in practice, if the socio-political context is not considered ${ }^{(25)}$. Emphasis should also be placed on the need to work with socially vulnerable groups, today called "key populations", and to identify and adapt actions consistent with each location and context. Declining popular participation and a lack of emphasis on human rights result in poorer public policies, thus reflecting the violation of human rights to PLHIV/AIDS ${ }^{(6)}$.

The study data point to the challenge of the health system for the establishment of actions that guarantee continuous care and the bond of these individuals with the services, since the lack of outpatient appointments represents a risk factor for hospitalization. Thus, the health system is expected to offer early diagnosis, timely treatment and adequate follow-up of PLHIV. Moreover, considering the different vulnerabilities of PLHIV in this context is to reflect on the need for intersectoral permeability in the establishment of the care plan and actions offered. There is mobilization of social subjects and political resources to include more vulnerable subjects from the focus of actions and services beyond the health context.

Thinking about reducing existing vulnerabilities, both for HIV infection and for those immersed in the life and health context that PLHIV/AIDS are exposed to, presupposes considering each person as a rights holder. Moreover, there is monitoring of the actions of governors in relation to the proposition of projects that 
Vulnerability factors associated with HIV/AIDS hospitalizations: a case-control study Lopes LM, Andrade RLP, Arakawa T, Magnabosco GT, Nemes MIB, Ruffino Netto A, et al.

guarantee citizenship strengthening ${ }^{(6)}$. Given this, considering the existence of factors related to social, individual and programmatic vulnerabilities that directly interfere with HIV hospitalizations, it is clear that the problem transcends the health sector. Articulation with the educational and social assistance sectors is necessary, since PLHIV/AIDS are inserted in a society that must guarantee, at a minimum, citizenship rights. Therefore, the present study points to the urgent need to structure and implement intersectoral public policies to positively impact the management of this chronic condition. Nursing plays a fundamental role and can contribute to reduce unfavorable outcomes, such as hospitalizations due to the disease.

\section{Study limitations}

As limitations of this study, it is recognized that, because this is a retrospective analysis, there may be the occurrence of memory bias during interviews with HIV people hospitalized and not hospitalized, in addition to information bias due to secondary sources use, which may contain registry failures.

\section{Contributions to nursing, health or public policy}

This study aimed to produce theoretical and operational knowledge by identifying factors associated with HIV/AIDS hospitalizations. This knowledge has the potential to support the direction of public health policies for effective planning and management of local care for PLHIV/AIDS.

\section{CONCLUSIONS}

Individual, social and programmatic vulnerabilities such as being unemployed or retired or homemaker, living on the street, using drugs, not using ART on a regular basis, having a history of treatment withdrawal, missing return visits and not being attended by social worker constitute risk factors for HIV/AIDS hospitalization.

Given these findings, it is urgent to consider the several dimensions in tackling the AIDS epidemic. Coping must be based on the constitution of unique therapeutic plans that are consistent with the real needs and demands presented by HIV individuals. There is an urgent need to strengthen specialized HIV/AIDS services, especially regarding the composition of minimum teams. The presence of the social worker stands out, whose look and field of practices/knowledge enhance health care production and management, matching them to the challenges that permeate grievance management as a chronic condition immersed in different social and health contexts.

\section{FUNDING/ACKNOWLEDGMENT}

A special thanks to the Coordination for the Improvement of Higher Education Personnel (CAPES - Coordenação de Aperfeiçoamento de Pessoal de Nível Superior) and the Brazilian National Council for Scientific and Technological Development (CNPq - Conselho Nacional de Desenvolvimento Científico e Tecnologico) (Process 148897/2014-2), for the grant of doctoral scholarships. To Lis Aparecida de Souza Neves and Maria Amelia Zanon Ponce, for having participated in the conclusion bench of this Doctorate.

\section{REFERENCES}

1. Villarinho MV, Padilha MI, Berardinelli LMM, Borenstein MS, Meirelles BHS, Andrade SR. [Public health policies facing the epidemic of AIDS and the assistance for people with the disease]. Rev Bras Enferm. 2013.66(2):271-7. doi: 10.1590/S0034-71672013000200018 Portuguese.

2. Mendes EV. [Health care networks]. Ciênc Saúde Coletiva. 2010. 15(5):2297-305. doi: 10.1590/S1413-81232010000500005 Portuguese.

3. Kok S, Rutherford AR, Gustafson R, Barrios R, Montaner JSG, Vasarhelyi K. Optimizing an HIV testing program using a system dynamics model of the continuum of care. Health Care Manag Sci. 2015. 18(3):334-62. doi: 10.1007/s10729-014-9312-0.

4. Ministério da Saúde (BR). Protocolo clínico e diretrizes terapêuticas para manejo da infecção pelo HIV em adultos. Brasília: Ministério da Saúde; 2013. 217 p.

5. Bachhuber MA, Southern WN. Hospitalization rates of people living with HIV in the United States, 2009. Public Health Rep. 2014. 129(2):17886. doi: $10.1177 / 003335491412900212$

6. Paiva V, Ayres JR, organizadores. Vulnerabilidade e Direitos Humanos: Prevenção e Promoção da Saúde. Curitiba: Juruá; 2012.320 p.

7. Ministério da Saúde (BR). Recomendações para terapia anti-retroviral em adultos infectados pelo HIV. Brasília: Ministério da Saúde; 2008.244 p.

8. Marcial TM, Castro JGF. Acompanhamento ambulatorial do paciente com HIV/AIDS. In: Fundação Hospitalar do Estado de Minas Gerais (FHEMIG). Caderno de protocolos clínicos da FHEMIG [Internet]. Belo Horizonte: FHEMIG, 2010 [cited 2017 May 25]. p. 97-101. Available from: http://www.fhemig.mg.gov.br/index.php/docman/Publicacoes-3/ Publicacoes_Institucionais/1215-ed-cadernos-protocolos-fhemig-2010/file.

9. Almeida $\mathrm{CM}$, Macinko J. Validação de uma metodologia de avaliação rápida das características organizacionais e do desempenho dos serviços de atenção básica do Sistema Único de Saúde (SUS) em nível local. 1. ed. Brasília: Organização Panamericana da Saúde; 2006.215 p.

10. Galvão MTG, Soares LL, Pedrosa SC, Fiuza MLT, Lemos LA. Quality of life and adherence to antiretroviral medication in people with HIV. Acta Paul Enferm. 2015. 28(1):48-53. doi: 10.1590/1982-0194201500009

11. Escorel S. Vidas ao léu: trajetórias de exclusão social. Rio de Janeiro: Fiocruz; 1999. 276 p.

12. Akerman M, Sá RF, Moyses S, Rezende R, Rocha D. Intersectoriality? Intersectorialities! Ciênc Saúde Coletiva. 2014. 19(11):4291-300. doi: 10.1590/1413-812320141911.10692014

13. Ministério do Desenvolvimento Social e Combate à Fome (BR). Orientações Técnicas: Centro de Referência Especializado para População em Situação de Rua - Centro Pop. Brasília: Editora Brasil; 2011. 116 p. 
Vulnerability factors associated with HIV/AIDS hospitalizations: a case-control study

14. Serafino L, Luz LCX. [Policies for the Adult Population Living on the Streets: Questions for Debate]. Rev Katálysis. 2015. 18(1):74-85. doi: $10.1590 / 1414-49802015000100008$

15. Nunes AA, Caliani LS, Nunes MS, Silva AS, Mello LM. Profile analysis of patients with HIV/AIDS hospitalized after the introduction of antiretroviral therapy. Ciênc Saúde Coletiva. 2015. 20(10):3191-8. doi: 10.1590/1413-812320152010.03062015

16. Joint United Nations Programme on HIV/Aids. 90-90-90: an ambitious treatment target to the help end the AIDS epidemic. Geneve: UNAIDS; 2014. 33 p.

17. Nemes MIB, Castanheira ERL, Helena ETS, Melchior R, Caraciolo JM, Basso CR, et al. Treatment adherence, access and AIDS assistance quality in Brazil. Rev Assoc Med Bras. 2009;55(2):207-12. doi: 10.1590/S0104-42302009000200028.

18. Grangeiro A, Castanheira ER, Nemes MIB. The reemergence of the aids epidemic in Brazil: challenges and perspectives to tackle the disease. Interface. 2015. 19(52):5-6. doi: 10.1590/1807-57622015.0038

19. Achappa B, Madi D, Bhaskaran U, Ramapuram JT, Rao S, Mahalingam S. Adherence to antiretroviral therapy among people living with HIV. N Am J Med Sci. 2013. 5(3):220-3. doi: 10.4103/1947-2714.109196

20. Santos El, Silva AL, Santana PPC, Teixeira PA. [Brazilian scientific evidence on adherence to antiretroviral therapy by patients with HIV/AIDS]. Rev Eletrôn Gestão Saúde [Internet]. 2015 [cited 2018 Nov 29];7(1):454-70. Available from: http://periodicos.unb.br/index.php/rgs/article/ view/22092. Portuguese.

21. Fielden SJ, Rusch ML, Levy AR, Yip B, Wood E, Harrigan RP, et al. Predicting hospitalization among HIV-infected antiretroviral naïve patients starting HAART: determining clinical markers and exploring social pathways. AIDS Care. 2008. 20(3):297-303. doi: 10.1080/09540120701561296

22. Lopes LM, Magnabosco GT, Andrade RLP, Ponce MAZ, Wysocki AD, Ravanholi GM, et al. [Coordination of care for people living with HIV/AIDS in a city in São Paulo State, Brazil]. Cad Saúde Pública. 2014; 30(11):2283-97. doi: 10.1590/0102-311X00091213 Portuguese.

23. Azevedo V. [The professional practice of social worker in the treatment for HIV/AIDS in Brazil]. Intervenção Social [Internet]. 2015 [cited 2018 Fev 05];(46):41-6. Available from: http://revistas.lis.ulusiada.pt/index.php/is/article/view/2356/2495. Portuguese.

24. Sposati A. [Social protection and social security in Brazil: agenda for the social worker's work]. Serv Soc Soc. 2013. (116):652-74. doi: 10.1590/ S0101-66282013000400005 Portuguese.

25. Paiva V, Ferguson L, Aggleton P, Mane P, Kelly-Hanku A, Giang LM, et al. The current state of play of research on the social, political and legal dimensions of HIV. Cad Saúde Pública. 2015. 31(3):477-86. doi: 10.1590/0102-311x00172514 